\title{
Memorandum di Masa Pemerintahan Abdurrahman Wahid dalam Perspektif Hukum Tata Negara Islam
}

\author{
Misbahuddin \\ \begin{tabular}{l|l} 
misbah_udin@yahoo.co.id & $\begin{array}{l}\text { Jl. Kejawan Putih Tambak, Gg. Masjid } \\
\text { No.5 Mulyorejo Surabaya, Indonesia }\end{array}$
\end{tabular}
}

\begin{abstract}
The tide of democratization in Indonesia has radically changed the structure of Indonesian politics since the overthrown of New Order government by the reform movement in 1998. One important change is the essential vitality of parliamentary politics in Indonesia. In the era of Abdurrahman Wahid's government, the DPR's role was more independent and had a loud voice constraining the executive's running. As a result, the Indonesian constitution which is based on the Presidential system seems to have deviated to being a Parliamentary System. An example of tension is the birth of a memorandum. This paper seeks to examine the "Memorandum during the Government of Abdurrahman Wahid" from the perspective of Islamic State Administration Law. This paper concludes based on the Islamic State Administration Law that the Abdurrahman Wahid's Government Memorandum is invalid because the warning or redressal requirements for a president must be preceded by evidence of deviation from religion.
\end{abstract}

KeyWord: Memorandum, Islamic Administration Law, Right of DPR.

\begin{abstract}
Abstrak: Arus demokratisasi di Indonesia telah mengubah secara fundamental struktur politik Indonesia semenjak pemerintahan orde baru ditumbangkan oleh gerakan reformasi pada tahun 1998. satu perubahan penting itu adalah semakin vitalnya politik parlemen di Indonesia. Dalam era pemerintahan Abdurrahman Wahid, peranan DPR kian independen dan bersuara lantang mengontrol jalannya eksekutif. Akibatnya Indonesia yang konstitusinya didasarkan pada Sistem Presidensiil seolah-olah telah melenceng menjadi Sistem Parlementer. Salah satu bentuk ketegangan tersebut adalah lahirnya memorandum. Tulisan ini berusaha mengkaji "Memorandum di masa Pemerintahan Abdurrahman Wahid" dalam perspektif Hukum Tata Negara Islam. Kesimpulan dari tulisan ini adalah bahwa dalam pandangan Hukum Tata Negara Islam terhadap Memorandum masa Pemerintahan Abdurrahman
\end{abstract}


Wahid adalah tidak sah, karena persyaratan peringatan atau pelurusan terhadap seorang pemimpin harus didahului dengan adanya bukti penyimpangan terhadap agama.

Kata kunci: memorandum, hukum tata negara Islam, kewenangan DPR.

\section{Pendahuluan}

Arus demokratisasi di Indonesia telah mengubah secara fundamental struktur politik Indonesia semenjak pemerintahan orde baru ditumbangkan oleh gerakan reformasi pada tahun 1998. Satu perubahan penting itu adalah semakin vitalnya politik parlemen di Indonesia.

Memiliki pemerintahan yang totalitas seperti pengalaman hidup baru. Bersama orde baru tiga dasawarsa lebih, sama berbahayanya dengan memiliki pemerintahan yang rapuh dan gampang dijatuhkan. Pemerintahan totalitas akan membuat parlemen hidup di bawah kendalanya, atau bahkan melenyapkannya sama sekali. Namun sebaliknya, pemerintahan yang mudah dijatuhkan oleh parlemen akan menghasilkan kekacauan yang berulang-ulang dalam praktek penyelenggaraan negara. ${ }^{1}$

Selama lebih dari tiga puluh tahun, kita hidup di bawah pemerintahan yang totalitas. Pengalaman perih itu telah membuat kita jera dan sangat sensitif terhadap praktek-praktek pemerintahan yang tidak accountable. Sensitifitas inilah yang kemudian membuat orang lupa atau acap terlambat sadar menyoroti kinerja para politisi di DPR dan MPR, lembaga terhormat yang dulu tak ubahnya dibuat hanya sebagai label dari keputusan-keputusan orde baru.

Accountability parlemen itu bermakna setiap wakil rakyat harus menjalankan mandatnya untuk mengontrol pemerintahan semata-mata berdasarkan prinsip-prinsip konstitusionalisme. Di sini sangat penting bagi kita untuk memastikan The Ethnic of Parliamentarism tumbuh dan dipatuhi oleh wakil rakyat kita di DPR dan MPR. ${ }^{2}$

${ }^{1}$ Fraksi Kebangkitan Bangsa DPR-RI, Buku Putih: Menegakkan Kebenaran (Jakarta: Bumi Selamat Printing, 2001), xi.

2 Fraksi Kebangkitan Bangsa DPR-RI, xii. 
Dalam era pemerintahan Abdurrahman Wahid, peranan DPR kian independen dan bersuara lantang mengontrol jalannya eksekutif. Tetapi dalam perkembangan berikutnya atmosfer kebebasan di dalam era pemerintahan Abdurrahman Wahid membuat sebagian kekuatan di parlemen terlihat semakin over acting memainkan peran kontrolnya terhadap eksekutif. Akibatnya Indonesia yang konstitusinya didasarkan pada Sistem Presidensiil seolaholah telah melenceng menjadi Sistem Parlementer.

Pelbagai kebijakan Presiden Abdurrahman Wahid yang semula mendapatkan dukungan dari parlemen sebagai manifestasi dari tuntutan reformasi di masa-masa akhir pemerintahannya justru mendapat kecaman keras. Tidak saja kebijakan yang ditujukan kepada militer, kebijakan yang menjadi Hak Prerogatifnya juga mendapat sorotan tajam dari politisi-politisi di DPR. Pemecatan Laksamana Sukardi dan Yusuf Kalla adalah salah satu contohnya. ${ }^{3}$

Selain itu, ketegangan Abdurrahman Wahid dengan parlemen juga tidak terlepas dari persoalan pembubaran Departemen Sosial (DEPSOS) dan Departemen Penerangan (DEPPEN). Pengajuan hak interplasi selama dua kali adalah salah satu contoh kongkrit bentuk ketidakpuasan sebagian besar anggota DPR terhadap presiden. ${ }^{4}$

Awal tahun 2001 tampaknya ketegangan antara presiden Abdurrahman Wahid dengan parlemen tidak mereda. Sebaliknya hubungan antara dua lembaga ini semakin memburuk. ${ }^{5}$ Ketidakharmonisan ini sangat mengganggu kinerja presiden dan parlemen, amat terrasa dengan ketegangan-ketegangan yang tidak ada hentinya. Puncak dari ketegangan ini adalah munculnya kasus dugaan penyelewengan Dana Yanatera Bulog dan bantuan dana dari

3 Hananto Widodo, "Politik Hukum Hak Interpelasi Dewan Perwakilan Rakyat Republik Indonesia," Jurnal Rechtsvinding: Media Pembinaan Hukum Nasional 1, no. 3 (Desember 2012): 429.

4 Malik Haramain, Gus Dur Militer dan Politik (Yogyakarta: LKiS, 2004), 272.

5 Widodo, "Politik Hukum Hak Interpelasi Dewan Perwakilan Rakyat Republik Indonesia," 431. 
Sultan Brunei yang kemudian populer dengan sebutan Buloggate dan Bruneigate.

Mencuatnya kasus ini kemudian berujung pada keputusan DPR membuat panitia khusus (Pansus) untuk menuntaskan kasus ini. Meski awalnya dan sampai akhir keputusan hasil kerja pansus, PKB sangat gigih menolak rencana ini, namun lewat perhitungan suara sebanyak 307 anggota DPR menyatakan menerima penggunaan hak untuk melakukan penyelidikan dana Yanatera Bulog dan bantuan Sultan Brunei. Tiga diantaranya menolak dan 45 lainnya menyatakan abstain. ${ }^{6}$

Dalam kasus penggunaan Dana Non-Budgeter Bulog ini, tokoh-tokoh orde baru yang diselidiki perannya termasuk mantan kepala Bulog yaitu Bustanil Arifin, Beddu Amang, Rahadi Ramelan, Wakil Presiden Yusuf Kalla dan Akbar Tandjung yang pada masa pemerintahan Presiden Habibie menjabat sebagai Menteri Sekretaris Negara. ${ }^{7}$

Dalam perjalanan kinerja Pansus Buloggate dan Bruneigate hingga kemudian berujung pada keputusan menjatuhkan Memorandum kepada Abdurrahman Wahid sampai pencopotan jabatan presiden oleh MPR telah menimbulkan kontroversi dan silang pendapat di antara para pakar hukum ketatanegaraan di negeri ini. Yang menyetujui pencopotan tersebut berlandaskan bahwa Abdurrahman Wahid telah melanggar UUD Negara Republik Indonesia tahun 1945 pasal 9 mengenai sumpah jabatan Presiden, dan melanggar Undang-undang Republik Indonesia No. 28 Tahun 1998 tentang penyelenggaraan Negara yang Bersih dan Bebas KKN (Korupsi, Kolusi, dan Nepotisme). ${ }^{8}$

Terlepas dari silang pendapat mengenai sah dan tidaknya pencopotan Presiden, penulis di sini ingin kembali pada permasalahan memorandum yang menjadi penyebab lahirnya sidang istimewa tersebut. Menurut Tap MPR Nomor

${ }^{6}$ Haramain, Gus Dur Militer dan Politik, 273.

${ }^{7}$ Anonim, "Kasus Bulogate," Kompas, 19 Juni 2000, 4.

8 Muwahid, "Sistem Ketatanegaraan Indonesia Pasca Amandemen UUD 1945," Jurnal Al-Qānūn 13, no. 2 (Desember 2010): 498. 
III/MPR/1978 pasal 7 ayat 2 dijelaskan bahwa memorandum menjadi pilihan pernyataan pendapat oleh anggota Dewan jika Presiden sungguh-sungguh melanggar haluan negara (Memorandum I). Selanjutnya Memorandum II dikeluarkan anggota Dewan jika Presiden tidak memperhatikan dan sudah mencapai batas waktu 3 bulan.

Dalam Islam masalah penurunan kepala negara bukanlah hal yang baru, tetapi menjadi hal yang biasa terjadi dalam sistem ketatanegaraan. Di Islam juga terapat aturan dan mekanisme yang berisi mengenai pengangkatan kepala negara maupun memberhentikannya, disertai dengan syarat-syarat yang harus terpenuhi untuk mewujudkan hal tersebut.

Terkait pemaparan di atas, maka penulis merasa perlu melakukan kajian dengan tema "Memorandum di Masa Pemerintahan Abdurrahman Wahid dalam Perspektif Hukum Tata Negara Islām".

\section{Konsep Memorandum di Indonesia}

Secara etimologis memorandum diartikan sebagai bentuk peringatan. ${ }^{9}$ Sedangkan menurut terminologi hukum ketatan egaraan, memorandum adalah surat peringatan yang dikeluarkan oleh Lembaga Dewan Perwakilan Rakyat untuk mengingatkan Presiden apabila Presiden sungguh-sungguh melanggar Haluan Negara. ${ }^{10}$

Meskipun demikian, menurut Tata Tertib DPR pasal 165, memorandum ditempatkan sebagai salah satu bentuk pernyataan pendapat Dewan Perwakilan Rakyat. Pernyataan pendapat DPR tidak hanya berkutat pada pengawasan terhadap pelanggaran. Namun lebih dari itu, pernyataan pendapat juga dapat dilakukan untuk merespon kebijakan pemerintah dan kejadian luar biasa yang terjadi di tanah air, yang kemudian disertai dengan saran penyelesaian.

9 Pius A Partanto dan Al-Barry, Pius A Partanto dan M. Dahlan al- Barry. Kamus Ilmiah Populer. Surabaya: Arkola, 1994 (Surabaya: Arkola, 1994), 452.

10 Ketetapan MPR No. III/MPR/1978 tentang Kedudukan dan Hubungan Tata Kerja Lembaga Tertinggi Negara dengan atau antar Lembaga-Lembaga Tinggi Negara, pasal 7, 
Berkaitan dengan memorandum yang dijadikan bentuk pernyataan pendapat Dewan, maka prosedur yang harus dijalankan tentu harus sesuai dengan ketentuan Tap MPR Nomor III/MPR/1978. Dalam Pasal 7 ayat 2 dinyatakan bahwa presiden terbukti "sungguh-sungguh melanggar Haluan Negara". Adapun prosedur lanjut memorandum pertama seperti yang tertera dalam ayat 3, bahwa "Dewan Perwakilan Rakyat menyampaikan memorandum kedua apabila dalam waktu tiga bulan Presiden tidak memperhatikan memorandum dewan perwakilan rakyat". Pada ayat 4 dikatakan, "Apabila dalam waktu satu bulan memorandum yang kedua tersebut tidak diindahkan oleh Presiden, maka DPR dapat meminta MPR mengadakan sidang istimewa untuk meminta pertanggungjawaban Presiden". ${ }^{11}$

Secara devinitif, memorandum bukan hanya diperuntukkan kepada seorang presiden semata, namun juga dapat diberlakukan kepada pemimpin daerah, Sebagaimana yang dijelaskan dalam Undang-undang Susunan dan Kedudukan Lembaga Tertinggi Negara, No. 4 Tahun 1999 yang belum diamandemen, pada pasal 34 ayat (1), (2) dan (3) yang berbunyi:

(1) DPRD, sebagai Lembaga Perwakilan Rakyat di daerah, merupakan wahana untuk melaksanakan demokrasi berdasarkan pancasila.

(2) DPRD mempunyai tugas dan wewenang:

a. Memilih Gubernur/Wakil Gubernur, Bupati, Wakil Bupati dan Walikota/Wakil Walikota;

b. Mengusulkan mengangkatan dan pemberhentian Gubernur/Wakil Gubernur, Bupati/Wakil Bupati, dan Walikota/Wakil Walikota kepada presiden.

(3) Untuk melaksanakan tugas dan wewenang sebagaimana yang dimaksud ayat (2), DPRD mempunyai hak:

a. Meminta pertanggungjawaban Gubernur, Bupati, dan Walikota.

11 Arie Sulistyoko, "Pemakzulan Presiden dalam Persepsi Konstitusi (Studi Kasus Presiden Abdurrahman Wahid)," Syariah: Jurnal Hukum dan Pemikiran 16, no. 1 (Juni 2016): 71. 
b. Meminta keterangan kepada pemerintah daerah

c. Mengadakan penyelidikan

d. Mengadakan perubahan atas rancangan peraturan daerah;

e. Mengajukan pernyataan pendapat

f. Mengajukan rancangan peraturan daerah

g. Menentukan anggaran DPRD.

Dalam pasal yang tersebut di atas memorandum dapat diarahkan kepada siapa saja yang kebetulan mendapat kepercayaan dan amanat dari rakyat yang dipimpinnya. Bahkan sampai pada level keluarga, sehingga masalah yang dihadapi dapat dicarikan solusinya.

Dengan sendirinya, memorandum sangat erat dengan bentuk pertanggungjawaban. Dalam artian bahwa memorandum hanya signifikasi dalam mempertanggung jawabkan mandat yang tertuang dalam kesepakatan sosial.

\section{Konsep Memorandum di Negara Islam}

Dalam transliterasi Arab-Inggris, memorandum punya kesamaan arti dengan kata tadhkirah yang artinya peringatan. ${ }^{12}$ Memorandum dalam Islam ialah suatu peringatan yang diberikan kepada pemimpin yang telah melakukan kesalahan yang berhubungan dengan prinsipprinsip agama. Dalam pidato pengukuhan khalifah $\mathrm{Abu}$ Bakar ra. sebagai khalifah, beliau menekankan tentang ketaatan politik terhadap pemimpin sebagai berikut: "Bila saya melangkah di atas jalan yang benar, yakni syari'ah, maka ikutilah saya. Bila saya menyimpang, luruskan saya....".13

Dari pidato di atas, penulis dapat jelaskan bahwa kalimat "luruskan saya" mempunyai kesamaan arti dengan memorandum yang prosedurnya harus didahului dengan penyimpangan terhadap haluan negara dan bertujuan untuk memberikan solusi yang terbaik. Dalam konteks

12 Hasan S. Karmi, Al-Mughni al-Kabir Plus: A Dictionary of Contemporary English-Arabic (Beirut: Librairie du Libanon, 1944), 551.

13 Khalid Ibrahim Jindan, Teori Pemerintahan Islam; Menurut Ibnu Taimiyah (Jakarta: Rineka Cipta, 1994), 93. 
ketatanegaraan Islam, pemimpin berhak mendapat memorandum (pelurusan) jika dia melakukan penyimpangan terhadap haluan negara yang berupa syari'at.

Seruan pemberian peringatan yang disertai penyelesaian (pelurusan) oleh khalifah Abu Bakar ra. sesuai dengan etika dakwah yang tertera dalam QS. al-Nahl (14): $125 .{ }^{14}$

Dalam Tafsir al-Qurtubi dijelaskan bahwa Perintah untuk mengajak manusia ke jalan Allah dengan hikmah dan pelajaran yang baik selain untuk merespon kondisi orang kafir, namun juga diperuntukkan bagi orang Islam yang melakukan pelanggaran agama (maksiat). Tujuannya supaya kembali pada jalan yang diridloi Tuhan. ${ }^{15}$

Setelah penggunaan hikmah sudah selesai, hendaknya orang yang berhak memberi peringatan mengambil jalan kedua dengan menjelaskan implikasiimplikasi tindakan yang akan timbul seperti yang dialami oleh pendahulunya atau orang lain.

Kewajiban individual tersebut sesuai dengan sabda Nabi saw.: "Bila seseorang diantara kamu melihat kejahatan, ia diperintahkan untuk merubahnya dengan tangannya sendiri; jika tidak sanggup, hendaknya ia menegaskan bahwa perbuatan itu adalah perilaku dosa; dan kalau tidak bias demikian, maka ia harus yakin bahwa perbuatan itu adalah jahat. Inilah bentuk iman yang paling lemah."

Dalam kontek negara, Nabi saw. sudah mensinyalir adanya kewajiban untuk mengajak kebaikan oleh setiap element masyarakat andaikata menemui kejahatan. Bagi orang yang punya kekuasaan structural untuk merubah kemungkaran, maka hendaknya ia kerjakan kewajiban dengan kekuasaan (bi yadihi). Dan orang yang punya

14 Disebutkan dalam QS. al-Nahl (14): 125, yang artinya; "Serulah (manusia) kepada jalan Tuhanmu dengan hikmah dan pelajaran yang baik dan bantahlah mereka dengan cara yang baik. Sesungguhnya Tuhanmu Dialah yang lebih mengetahui tentang siapa yang tersesat dari jalan-Nya dan Dialah yang lebih mengetahui orang-orang yang mendapat petunjuk." Departemen Agama RI, Al-Qur'an Dan Terjemahannya (Semarang: Tanjung Mas Inti, 1992), 421.

15 al-Qurțūby, Tafsĩr al-Qurțuby al-Jämi' li Ahkām al-Qur'ān (Beirut: Dār ArRisālah, 2006), 359-60. 
kekuatan kultural, maka hendaklah ia melakukan kewajiban dengan kekuatan kulturalnya (bil lisānihi). Sedangkan bagi yang tidak punya kekuatan, maka cukup kiranya dia mengutuk dalam hatinya bahwa tindakan yang sedang diperagakan secara massal adalah tindakan yang menyimpang dari koridor agama (bi qalbihi).

Dengan begitu, selama pemimpin tidak melakukan tindakan yang dapat dikatagorikan menyimpang dari syari'at, maka peringatan atau pelurusan dengan tatacara dan oleh element masyarakat dimaksud tidak diperlukan. Bahkan pemimpin berhak mendapatkan ketaatan politik dari element masyarakat guna mendukung terselenggaranya kesejahteraan masyarakat, baik duniawi maupun ukhrowi.

\section{Kronologi Memorandum di Masa Pemerintahan Abdurrahman Wahid}

Pada dasarnya memorandum merupakan surat peringatan yang dikeluarkan oleh Lembaga Dewan Perwakilan Rakyat untuk mengingatkan Presiden. Namun lebih dari itu, pernyataan pendapat juga dapat dilakukan untuk merespon kebijakan pemerintah dan kejadian luar biasa yang terjadi di tanah air yang kemudian disertai dengan saran penyelesaian. ${ }^{16}$

Prosedur yang harus dijalankan bahwa jika presiden terbukti "sungguh-sungguh melanggar Haluan Negara". Selanjutnya, DPR dapat menyampaikan memorandum kedua apabila dalam waktu tiga bulan Presiden tidak memperhatikan memorandum DPR. berikutnya, apabila dalam waktu satu bulan memorandum yang kedua tersebut tidak diindahkan oleh Presiden, maka DPR dapat meminta MPR mengadakan sidang istimewa untuk meminta pertanggungjawaban Presiden. ${ }^{17}$

Adapun lahirnya memorandum dipicu oleh persoalan kasus korupsi Dana Yanatera Bulog dan sumbangan dari

16 Sulistyoko, "Pemakzulan Presiden dalam Persepsi Konstitusi (Studi Kasus Presiden Abdurrahman Wahid)," 72.

17 Fraksi Kebangkitan Bangsa DPR-RI, Buku Putih: Menegakkan Kebenaran, 27. 
Sultan Brunei Darussalam yang melibatkan presiden Abdurrahman Wahid. Namun sebelumnya perlu kita mengetahui asal muasal secara obyektif tentang dana tersebut. ${ }^{18}$

Dana yang dipersoalkan adalah yang bersumber dari Yanatera (Yayasan Bina Sejahtera) adalah sebuah yayasan keluarga Bulog yang didirikan tahun 1984 dan bertujuan untuk meningkatkan kesejahteraan keluarga dan karyawan Bulog. Dana yayasan diperoleh dari iuran anggota, bantuan Insidentil dari Bulog dan bantuan dari pihak lain yang tidak mengikat. Dana itu digunakan untuk kesejahteraan anggota, misalnya pemberian Tunjangan Hari Raya (THR) karyawan bulog, beasiswa anak-anak karyawan dan para pensiunan. Dana yayasan diputar, sehingga kekayaan terakhir per 31 Juli 2000 tercatat sebesar Rp 271.462.285.745,20 terdiri atas Saldo Kas dan Bank, Deposito, Piutang Soewondo, Piutang Pihak Ketiga, Penyertaan Modal dan Aktiva Tetap (WB,PY).

Bulog (Badan Usaha Logistik) adalah institusi pemerintah berbentuk badan yang bertugas utama menjaga stabilitas harga sembako. Disamping Bulog memiliki anggaran rutin dan anggaran operasional yang tercatat dalam Anggaran dan Belanja Negara (APBN), Bulog juga memiliki sejumlah dana yang tidak terpantau oleh Anggaran dan Belanja Negara (APBN), yang biasa disebut Dana NonBudgeter.

Persoalan Dana Non-Budgeter ini muncul ketika Presiden pernah tanya kepada Yusuf Kalla selaku Ketua Bulog tentang kemungkinan penggunaan Dana NonBudgeter untuk bantuan kemanusiaan di Aceh. Adapun wewenang pencairan dana tersebut adalah Ketua Bulog dengan surat persetujuan presiden. Setelah Sapuan sudah mendapat SK sebagai Wakil Ketua Bulog, dengan perantara Suewondo, Ia bertemu presiden dengan dua tujuan; Mengklarifikasi kebenaran permintaan presiden untuk

18 Sulistyoko, "Pemakzulan Presiden dalam Persepsi Konstitusi (Studi Kasus Presiden Abdurrahman Wahid)," 73. 
mencairkan dana untuk bantuan kemanusiaan. Dan menjelaskan rencana-rencana strategis Bulog ke depan. Dalam Klarifikasi tersebut Sapuan juga mengutarakan bahwa dana itu dapat dicairkan hanya dengan Keppres. Permintaan Sapuan kepada presiden untuk mengeluarkan Keppres ditolak dan tanpa memberi instruksi lain kecuali penyusunan paper pengalihan industri gula ke luar jawa.

Terhentinya masalah pencairan Dana pada Keppres bukan berarti masalah sudah selesai. Karena Soewondo yang mengaku sebagai asisten pribadi Presiden tetap berkomunikasi dengan Sapuan untuk mencairkan Dana bantuan kemanusiaan atas perintah Presiden. Dengan bantuan kata "atas perintah Presiden" inilah Sapuan memberanikan diri membuat "memo" agar Yusuf Kalla mencairkan Dana kemanusiaan dan sekaligus meminta tanda tangan Yusuf Kalla pada 2 lembar Cek Bank Bukopin yang masing-masing berisi 5 Milyar. Sebagai Ketua Bulog, Yusuf Kalla menolak untuk mencairkan Dana tersebut karena tidak ada surat perintah dari Presiden.

Kegagalan pencairan Dana Non-Budgeter diceritakan kepada Soewondo kemudian ia berkata" Kalau diijinkan, saya pinjam untuk pribadi saya yang nanti akan saya gunakan membangun rumah kebun". Setelah itu, Sapuan membuat memo pencairan Dana kepada Bendahara Yanatera Bulog untuk mengeluarkan dana sebesar 10 Milyar. Tanpa rapat pengurus dana tersebut dapat dicairkan dengan mudah dan langsung diberikan kepada Soewondo tanpa ada tanda terima. Dua hari kemudian Soewondo bilang bahwa dia tidak dapat memberikan tanda terima dari presiden. Meskipun begitu, Sapuan memberi lagi dana tambahan sebesar 25 Milyar kepada Soewondo yang kemudian menandatangani surat tanda terima dan kwitansi atas nama Soewondo tanpa disertai kata "atas perintah Presiden" dengan keperluan "pinjaman pemerintah untuk dana kemanusiaan". ${ }^{19}$

19 Fraksi Kebangkitan Bangsa DPR-RI, Buku Putih: Menegakkan Kebenaran, 37. 
Memasuki bulan Februari, Sapuan minta Soewondo untuk mengembalikan uang sebesar 35 Milyar, namun, kenyataan berbicara lain. Soewondo memberikan banyak alasan untuk mengulur waktu pembayaran. Demi menyelamatkan Dana Non-Budgeter, Sapuan minta surat perjanjian hutang piutang antara dirinya dan Soewondo selaku wiraswasta dengan jaminan tanah seluas 200 ha SHM di Cianjur dalam jangka setahun dengan bunga $18 \%$ yang dilaksanakan di depan Notaris.

Proses pencairan Dana Non-Budgeter Bulog yang begitu complicated justru berbeda dengan kasus bantuan Sulțan Brunei Darussalam. Setiap Bulan Syawal Sulțan dan keluarga kerajaan punya tradisi membagi-bagikan zakat baik kepada rakyatnya sendiri maupun Negara tetangga seperti Indonesia. Bertepatan Open House yang digelar Gus Dur, Ari Wowor memberikan informasi sekaligus minta tanggapan tentang bantuan tersebut.

Di kemudian hari, Ari Wowor bersama Haji Masnuh pergi ke Brunei Darussalam dengan biaya sendiri dan tanpa surat dari presiden atau yang mengatasnamakan pemerintah Indonesia. Bertemunya mereka dengan Sulțan memberikan berkah. Karena Sulțan memberikan uang US\$ 2000.000 (14 Milyar) untuk diberikan kepada masyarakat yang membutuhkan.

Adapun penyaluran dana bantuan kepada masyarakat yang membutuhkan tidak mungkin dibagikan secara merata dengan langsung terjun lapangan. Namun, seperti LSM, penyaluran bantuan lewat pengajuan proposal dari berbagai elemen masyarakat yang membutuhkan termasuk pengajuan proposal bantuan kemanusiaan dari Daerah Aceh.

Bantuan Sulțan Brunei adalah bantuan kemanusiaan untuk masyarakat Indonesia yang merupakan sebagian dari zakat yang dikeluarkan oleh keluarga kerajaan Brunei Darussalam. Karena itu, dana tersebut diserahkan sebagaimana layaknya menyerahkan zakat, tanpa ada proses administrasi pemerintahan dan tanpa perjanjian kenegaraan sebelumnya. Karena itu pula, Presiden tidak dilewati dan 
tidak mendapat bagian dana itu sebab tidak termasuk mustahiq zakat. ${ }^{20}$

Selain permasalahan di atas, Presiden juga dipusingkan dengan bagaimana menjalankan roda kekuasaan yang didasarkan atas kompromi dan tuntutan reformasi. Pada saat itu, Presiden telah memilih untuk meneruskan agenda reformasi dengan memecat dua menteri (Yusuf Kalla dan Laksamana Sukardi) yang kemudian menjadi sumber konflik antara Presiden dengan Dewan Perwakilan Rakyat. Maklum, keduanya adalah perwakilan partai besar yang menghuni Senayan. ${ }^{21}$

Ketegangan dengan Dewan Perwakilan Rakyat semakin memuncak dengan keputusan Presiden untuk memecat TNI (purn) Wiranto dan menonaktifkan Jenderal Pol. Suroko Bimantoro dan mengangkat yang lain sehingga terjadi dualisme dalam tubuh kepolisian. ${ }^{22}$

Belum ditemukannya solusi politik yang menguntungkan akibat kekecewaan partai besar, Presiden justru menebar wacana baru tentang pencabutan Tap MPR No. 25/MPRS/1966 tentang larangan ajaran Marxisme/Leninisme, dan mengusulkan pembukaan hubungan bisnis dengan Israel. Persoalan ideologi mendorong Presiden tidak hanya berhadapan dengan Lembaga Legislatif, namun ia berhadapan juga dengan kesadaran masyarakat luas. ${ }^{23}$

Melebarnya permasalahan tidak menjadikan Presiden Abdurrahman Wahid berhenti menjalankan tuntutan reformasi dengan membubarkan Departemen Sosial (Depsos) dan Departemen Penerangan (Deppen). ${ }^{24}$

20 Fraksi Kebangkitan Bangsa DPR-RI, 46.

21 Widodo, "Politik Hukum Hak Interpelasi Dewan Perwakilan Rakyat Republik Indonesia," 429.

${ }^{22}$ Abu Naim, "Tipologi Kepemimpinan Politik Gus Dur," Darussalam: Jurnal Pendidikan, Komunikasi, dan Pemikiran Hukum Islam VI, no. 1 (September 2014): 15.

23 A. Rosyid Al Atok, "Ketetatapn MPR dalam Hirerarki Peraturan Perundang-undangan," Jurnal Pendidikan Pancasila dan Kewarganegaraan 25, no. 1 (Pebruari 2012): 2.

24 Naim, “Tipologi Kepemimpinan Politik Gus Dur," 13. 
Kebijakan Presiden yang berorientasi pada jangka panjang mendapat reaksi dari Dewan Perwakilan Rakyat dengan menggagas adanya interpelasi kepada Presiden. ${ }^{25}$

Sikap reaktif anggota dewan dapat dimaklumi dengan dua alasan. Pertama, parlemen menggunakan hak prerogative presiden untuk meniadakan/mengadakan struktur kabinetnya serta memecat/mengganti menterimenterinya sebagai bahan utama interpelasi. Kedua, sikap konfrontasi Abdurrahman Wahid untuk tidak menyerah pada desakan parlemen meskipun mengatasnamakan kepentingan publik, dalam situasi di mana Abdurrahman Wahid lebih mempercayai tujuan jangka panjang kebijakannya daripada kerugian-kerugian di jangka pendek. ${ }^{26}$

Seperti biasanya Majelis Permusyawaratan Rakyat Pada bulan Agustus 2000, melaksanakan Sidang Tahunan dengan agenda meminta laporan kinerja Presiden selama setahun. Setelah ditelaah oleh semua anggota Majelis, muncul kesimpulan bahwa pemerintahan yang dikendalikan oleh Presiden Abdurrahman Wahid tidak efektif sehingga memerlukan pembagian tugas dengan wakil Presiden yang dituangkan dalam tap MPR No. VIII/MPR/2000 tentang laporan tahunan Lembaga Tinggi Negara. ${ }^{27}$

Atas desakan Majelis Permusyawaratan Rakyat, Presiden akhirnya juga membuat Kepres tentang pembagian tugas yang ternyata tidak menyelesaikan persoalan ketidakefektifan kinerja pemerintah. Setelah keluarnya Kepres itu kinerja pemerintah tidak kunjung efektif. Padahal setelah keputusan ini, yang memimpin dan mengkoordinasikan rapat dan kinerja kabinet adalah wapres. ${ }^{28}$

25 Haramain, Gus Dur Militer dan Politik, 273.

26 Naim, "Tipologi Kepemimpinan Politik Gus Dur," 15.

27 Atok, "Ketetatapn MPR dalam Hirerarki Peraturan Perundangundangan," 2 .

${ }^{28}$ Haramain, Gus Dur Militer dan Politik, 271. 


\section{Analisis Hukum Ketatanegaraan Islam terhadap Memorandum Pemerintahan Abdurrahman Wahid}

Dalam litaratur Hukum Tata Negara Islam tidak pernah menceritakan memorandum yang semula dibuat untuk pencarian solusi dari kebutuhan pemerintahan yang lebih lanjut sebagai komoditas politik. Sejarah pemerintahan Islam hanya bercerita tentang impeachments time dan prasyarat yang melingkupinya. Dengan begitu, permasalahan memorandum tidak pernah terendus sebagai permasalahan yang urgent dalam Sistem Ketatanegaraan Islam.

Tidak tersedianya tatacara dan etika empachment di atas justru memperkuat pendapat Mohammad Husain Haikal, yang menolak anggapan bahwa Islam itu lengkap dengan segala pengaturan bagi semua aspek kehidupan bermasyarakat, termasuk sistem politik. Namun, walaupun Islam tidak memberikan preferensinya kepada suatu sistem politik tertentu, ia telah meletakkan seperangkat prinsip atau tata nilai etika dan moral politik untuk dianut oleh umat Islam dalam membina kehidupan bernegara. ${ }^{29}$

Quthb berpendapat bahwa tidak ada orang atau lembaga yang memegang kekuasaan keagamaan dan mempunyai kewenangan sebagai wakil Tuhan di bumi. Baginya kepala negara adalah seorang penguasa sipil yang diangkat dan dapat diberhentikan oleh rakyat. ${ }^{30}$

Beralihnya otoritas Tuhan ke Rakyat dengan sendirinya memberikan konsekwensi logis terhadap konsep power sharing serta implementasi trias politika dalam system tata negara Islam dengan sungguh-sungguh dan selalu berkaitan dengan welfare atau kemaslahatan rakyat banyak. Tujuan pemerintahan yang selalu berorientasi pada aspek kemaslahatan rakyat di atas sesuai dengan kaidah fiqh sebagai berikut:

29 Munawir Sjadzali, Islam dan Tatanegara: Ajaran Sejarah dan Pemikiran (Jakarta: UI Press, 1993), 208.

30 Naim, “Tipologi Kepemimpinan Politik Gus Dur," 206. 


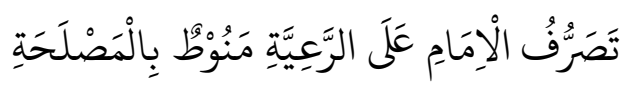

Artinya: "Kebijakan seorang imam terhadap rakyat selalu bertautan dengan kemaslahatan ".31

Istilah kesejahteraan (welfare) atau maşlahah adalah kondisi ideal yang dicapai oleh manusia dengan terpenuhinya kebutuhan. Baik primer (darüriyyah), sekunder (hajiyah) dan tersier (tahśiniyyah) secara berkesinambungan. ${ }^{32}$

Dengan begitu, kebutuhan primer manusia adalah sesuatu yang jika tidak dipenuhi akan mengakibatkan tidak berfungsinya kehidupan, ketidakteraturan dan kehancuran. Dan instabilitas dalam kehidupan ini tidak akan terjadi jika agama, nyawa, rasio, kehormatan dan harta mendapatkan perlindungan hukum. Kebutuhan sekunder (hajiyah) adalah sesuatu yang berfungsi mempermudah dan meringankan dalam kehidupan dengan diberlakukan dispensasi (rukhșah) dalam Ibadah dan sebagainya. Kebutuhan tersier (tahśiniyyah) adalah sesuatu yang berorientasi pada estetika dan etika yang diejawantahkan dalam Ibadah yang berupa urgensi kesucian dalam ritual; Mu'amalah, yang berupa tidak diperbolehkannya penipuan dalam jual beli; Jinayah, yang berupa larangan pembunuhan anak, perempuan dan sebagainya. ${ }^{33}$

Kesejahteraan manusia dalam tradisi pengetahuan Ushul Fiqh, berupa maślahah, bukan istilah baru karena ia sangat terkait dengan pemberlakuan syariat kepada umat manusia. Maślahah diposisikan sebagai tujuan diberlakukan syariat bagi manusia. Dengan begitu, tujuan syariat hanya untuk mewujudkan dan melindungi terhadap kesejahteraan

31 Muhamad Yasin Isa, Al-Fawảid al-Jāniyyah (Beirut: Maktabah Al-Buhūth wa al-Dirāsāt, 1997), 395.

32 Iffah Muzammil, "Maṣlaḥah sebagai Sumber Hukum Islam menurut Najm al-Din Al-Ṭüfy," Jurnal Al-Qānūn 13, no. 1 (Juni 2010): 87-88.

33 Abdul Basith Junaidy, "Menimbang Mașlahah sebagai Dasar Penetapan Hukum (Kajian terhadap Pemikiran Muhammad Abu Zahrah)," Jurnal Al-Qānūn 18, no. 2 (Desember 2015): 356-57. 
manusia, tentu secara proporsional sesuai dengan rumusan kebutuhan. ${ }^{34}$

Kesejahteraan rakyat sangat signifikan diperbincangkan pada masa kini. Mengingat rakyat bukan lagi diposisikan sebagai spesies manusia yang masih dalam "proses manipulasi". Namun ia adalah manusia yang kebetulan teridentifikasi secara politik sebagai rakyat yang seharusnya punya hak yang sama dengan penguasa dalam memperoleh kesejahteraan dan memperoleh perlindungan hukum. ${ }^{35}$

Dalam kasus memorandum atau bahkan impeachment, yang bukan menjadi barang tabu dalam era demokrasi politik, kesejahteraan rakyat harus selalu dan selamanya dijadikan sebagai tolok ukur keberhasilan dan gagalnya suatu pemerintahan. Tentunya dengan penelitian yang dapat dipertanggungjawabkan.

Dari paparan di atas, dapat disimpulkan bahwa kebutuhan agama adalah faktor terpenting dalam menentukan kesejahteraan rakyat. Namun, realisasi kebutuhan paling primer tersebut akan terhambat dengan tidak adanya aspek materi.

Maka, kebutuhan rakyat terhadap materi juga menjadi keharusan dalam rangka mewujudkan kesejahteraan. Hal ini sesuai dengan kaidah ushul fiqh sebagai berikut;

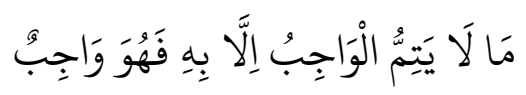

"Sesuatu dapat dikatakan wajib jika kewajiban utama tidak dapat terealisasi karena sesuatu tadi". ${ }^{36}$

Kiranya dapat disimpulkan bahwa degree of necessity dalam mewujudkan kesejahteraan rakyat adalah agama,

34 Menurut al-Maudūdy, dalam konsep pemerintahan Islam, salah satunya harus terdapatn "Rakyat mempunyai hak untuk menggugat para penguasa dan pemerintah". Tentunya dengan mekanisme yang sesuai dengan syariat Islam. Lihat: Idri, "Sistem Politik dan Pemerintahan Islam dalam Perspektif Abū al-A'lā al-Maudūdy," Jurnal Al-Qānūn 11, no. 1 (t.t.): 108.

35 Idri, 109.

${ }^{36}$ Abū Isḥāq al-Shirazy Fairuzabadi, Al-Luma’ fi Ușul al-Fiqh (Surabaya: Maktabah Muhammad Bin Ahmad Nabban wa Auladuh, t.t.), 10. 
nyawa, rasio, harga diri dan harta secara factual. Dengan begitu, pemerintah yang tidak mampu mensejahterahkan rakyat secara komprehensip sudah barang tentu memenuhi persyaratan untuk diberhentikan oleh lembaga legislative.

Pemberhentian seseorang dari jabatannya adalah wujud dari fenomena hukuman dalam perpektif politik yang dapat saja dialami setiap orang yang mana tidak kunjung menunjukkan loyalitas terhadap rakyat. Namun tidaklah bijaksana jika semua permasalahan yang melibatkan kepala negara harus selalu berujung dengan pemakzulan dari posisinya.

Meskipun para teoritis Sunni sepakat bahwa kepatuhan pada penguasa merupakan suatu keharusan, namun mereka juga sepakat dengan satu klausal politik selama penguasa tidak menyeleweng (jair). Ketika penguasa sudah maksiat, maka tidak ada ketaatan.

Dalam konteks ini, umat diperkenankan bahkan diharuskan untuk senantiasa melakukan kritik terhadap para penguasa. Kritik ini bertujuan agar proses pengambilan keputusan dan pelaksanaan kebijaksanaan di lapangan tidak membawa kepada kerusakan sendi-sendi kemasyarakatan.

Prinsip kritik dan nasehat sebagai keharusan dalam hubungan antara sesama warga negara dan antara warga negara dengan penguasa yang tidak diletakkan dalam kerangka absoluistik itu, dalam kombinasi dengan doktrin musyawarah (shüra) dan pemilihan (ikhtiyar) dalam pengangkatan pemimpin, melahirkan sistem sosial politik yang terbuka, yang menuntut partisipasi semua lapisan masyarakat atas dasar prinsip persamaan dan kewajiban.

Memang benar, jika kesejahteraan rakyat adalah tolok ukur pemberhentian seorang pemimpin negara, sehingga sungguh tidak rasional jika pemimpin yang benarbenar tidak berupaya untuk mensejahterakan rakyat tidak langsung diberhentikan, namun harus mendapat peringatan terlebih dahulu. Tujuannyya agar dapat mencari solusi dari permasalahan yang ada. Di samping supaya pemimpin dapat kembali punya keinginan dan keyakinan dalam upaya 
mensejahterakan rakyat mulai dengan hikmah, mau'izah hasanah dan mujädalah.

Logika yang dipakai dalam pemberian peringatan terlebih dahulu sebelum pemberhentian adalah andaikata pemimpin berhasil disadarkan oleh lembaga yang punya kompetensi, maka kehidupan rakyat yang jauh dari garis kesejahteraan dapat dibenahi kembali dengan bekal keberhasilan kompromi politik antar elemen bangsa. Lagi pula wacana kesejahteraan rakyat sangat mudah dimanipulasi demi kepentingan politik tertentu. ${ }^{37}$

Lebih dari itu, keberhasilan memorandum akan mengurangi mafsadah yang lebih besar terhadap rakyat. Karena bukan rahasia lagi jika pemberhentian seorang pemimpin negara akan menimbulkan instbalititas dalam semua sendi-sendi kehidupan. Tentunya tidak adanya kesejahteraan yang melanda rakyat akan sulit terselesaikan, walaupun dengan program baru. Logika ini diperkuat oleh kaidah fiqh sebagai berikut :

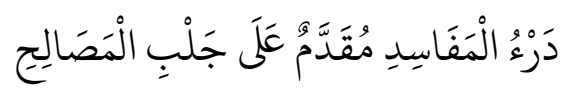

Artinya: "Menolak adanya kerusakan itu lebih diutamakan dari pada mengambil kemaslahatan". ${ }^{38}$

Ilustrasi memorandum atau peringatan sebelum datangnya implikasi dari perbuatannya sebenarnya dapat ditemukan dalam traktat perjalanan dakwah Nabi saw. sebagai khalifah Tuhan di bumi. Beliau saw. selalu menjalankan tugas sebagai nadhïr dan bashïr (pemberi peringatan dan pemberi kabar kebahagiaan terhadap umat).

Dalam menghadapi orang-orang yang kafir atau orang Islam yang kembali melakukan maksiat, maka perintah Tuhan adalah: pertama, Nabi seharusnya memperlihatkan kebenaran-kebenaran yang ada dalam kitab suci (hikmah)dengan asumsi orang tersebut tidak mengetahui apapun tentang kebenaran. Kedua, Nabi seharusnya memberikan nasehat atau kritik yang

37 Idri, "Sistem Politik dan Pemerintahan Islam dalam Perspektif Abū al-A'lā al-Maudūdy," 108.

38 Isa, Al-Fawảid al-Jāniyyah, 260. 
proporsional terhadap apa yang dilakukan orang tersebut (mau'idoh hasanah) dengan asumsi dia punya sedikit pengetahuan. Ketiga, Nabi seharusnya menapaki jalan agumentatif (mujadalah), dengan asumsi pelaku kemaksiatan sudah banyak tahu tentang kebenaran yang tidak sampai ke tataran keyakinan.

Itu semua penting dilakukan karena tugas Nabi hanya memberi peringatan, sedangkan hanya Tuhan yang tahu mana umat yang mendapat petunjuk dan mana umat yang benar-benar sesat dari jalan-Nya. Namun kalau semuanya tidak berhasil, maka datanglah siksaan dari Tuhan.

Formulasi traktat perjalanan dakwah Nabi di atas, kalau diterapkan dalam sistem ketatanegaraan Islam yang seperti ditegaskan oleh Quthb di atas dengan menggunakan preference of analogy (qiyas aulawi) akan menghasilkan penalaran memorandum sebagai berikut:

Pertama, posisi Nabi dalam realitas dakwah sama dengan posisi ahl al-hall wa al-'aqd yang punya tugas menyampaikan ketentuan undang-undang yang berlaku dan memberikan peringatan dan kabar gembira serta selalu melakukan pengawasan.

Kedua, Tuhan yang dalam realitas dakwah sebagai pemegang otoritas tertinggi terhadap kehidupan manusia sebetulnya dalam formulasi politik dapat bermetamorfosis menjadi keinginan dan kehendak rakyat. Rakyat dalam system politik ini adalah pemegang otoritas tertinggi dalam menentukan arah kehidupan bangsa, yang mana keinginan dan kehendaknya sama dengan suara Tuhan.

Ketiga, permasalahan yang ada dalam dunia politik dan dakwah mengarah pada titik temu yang sama ('ilah), berupa pelanggaran terhadap kesejahteraan secara komprehensip.

Dari penalaran analogis tersebut dapat disimpulkan bahwa pentingnya memorandum terhadap orang yang sengaja menanggalkan kesejahteraan dirinya atau orang lain sebelum datangnya siksaan dari Tuhan dalam dunia dakwah, justru lebih penting dan rasional jika memorandum diberikan kepada pemimpin yang keluar dari koridor 
kesejahteraan. Karena hal ini akan memberikan dampak yang lebih besar terhadap kondisi bangsa secara total jika mandataris rakyat diberhentikan tanpa diberikan kesempatan untuk melakukan pertaubatan.

Dengan begitu, peringatan atau memorandum adalah jalan menuju lahirnya siksaan atau impeachment dalam dunia politik. Namun itu semua dapat dihentikan jika kompromi politik dalam proses memorandum dapat memberikan solusi terbaik bagi bangsa.

Berbicara tentang pelanggaran Abdurrahman Wahid ketika menjadi presiden tentunya sangat jauh dari parameter yang sesungguhnya berupa terkoyaknya kesejahteraan rakyat. Keluarnya memorandum yang diprakarsai oleh Dewan Perwakilan Rakyat tidak pernah didasarkan pada hasil penelitian terhadap kondisi rakyat yang sebenarnya. Walaupun harus diakui Rakyat pada kurun waktu 2,5 tahun sangat sulit dinilai apakah in welfare atau out of welfare.

Namun, Dewan Perwakilan Rakyat selalu mengumbar nafsu politiknya tanpa batas. Akibatnya dalam prakteknya selalu menafikan klausul hukum yang berlaku di negara dan memanipulasi keinginan dan kehendak rakyat sebagai pemegang otoritas tertinggi dalam perjalanan demokrasi.

Pada hakekatnya, memorandum yang terjadi pada masa pemerintahan Abdurrahman Wahid adalah menyangkut persoalan pidana, Yaitu dugaan penyelewengan terhadap Dana Yanatera Bulog dan dana bantuan dari Sultan Brunei Darussalam yang dikenal dengan Buloggate dan Bruneigate.

Sedangkan dalam hukum tata negara Islam memorandum atau pelurusan hanya dikeluarkan pada saat presiden (sultān atau khalifah) terbukti telah melakukan kesalahan yang prinsipil dalam urusan agama dengan melakukan penyimpangan terhadap syari'ah.

Berbicara lebih lanjut tentang dugaan keterlibatan Presiden Abdurrahman Wahid dalam perbuatan yang dapat digolongkan munkar atau tidak sesuai dengan prinsipprinsip syari'ah, sudah selayaknya tidak dapat dijadikan 
pedoman untuk memberikan peringatan atau pelurusan. Dalam kaidah fiqh disebutkan bahwa:

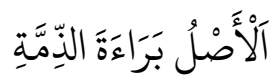

Menurut hukum asal, manusia bebas dari beban hukum.

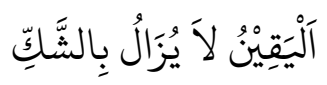

Keyakinan tidak dapat dihilangkan dengan dugaan. ${ }^{39}$

Dari kaidah-kaidah fiqh tersebut kiranya dapat diambil kesimpulan bahwa Abdurrahman Wahid dalam masalah Bullogate dan Bruneigate masih dalam status tidak melanggar prinsip agama. Status bebas dari perbuatan yang berdimensi kejahatan yang disandang oleh presiden adalah keyakinan yang tidak mungkin dimarjinalkan atau dikaburkan demi menegakkan hukum yang masih dalam katagori dugaan.

Oleh karena itu, sebelum lembaga yang berwenang memberikan peringatan atau pelurusan, maka seharusnya masalah yang dihadapi Presiden Abdurrahman Wahid di serahkan terlebih dahulu kepada lembaga yudikatif (alsultah al-qada'iyah).

Untuk meminimalisasikan dampak dari kebebasan dalam praktek transisi demokrasi yang dilakukan oleh Dewan Perwakilan Rakyat, seharusnya kedaulatan hukum dalam mengawal demokrasi harus mendapat perhatian dari seluruh element bangsa. Lebih lanjut, menurut Krabbe, itu semua dilakukan untuk mengantisipasi ketegangan antar lembaga politik dalam rangka implementasi trias politika yang berjalan baik di negara Indonesia maupun negara Islam.

Namun jika semuanya sulit diharapkan, maka kehendak dan keinginan rakyatlah yang terbungkus dalam kesejahteraan, seperti ditegaskan oleh Rossuae, yang menjadi penentu dalam penuntasan permasalahan yang terjadi. Karena kehendak rakyat adalah manifestasi dari kebenaran Tuhan yang universal.

39 Isa, 182. 


\section{Penutup}

Dari pembahasan yang telah dipaparkan sebelumnya, maka dapat disimpulkan bahwa dalam pandangan Hukum Tata Negara Islam terhadap Memorandum masa Pemerintahan Abdurrahman Wahid adalah tidak sah, karena memorandum hanya dijatuhkan manakala presiden telah terbukti melakukan perbuatan munkar atau telah melakukan perbuatan yang dapat dikategorikan menyimpang dari prinsip syari'ah yang terkodifikasi dalam upaya mensejahterakan rakyat.

Selanjutnya diajukan saran sebagai berikut:

1. Seharusnya trias politika yang sudah berkembang dalam tradisi demokrasi baik di Indonesia maupun Islam dijalankan dengan semestinya oleh Lembaga Tinggi Negara demi mempertimbangkan kondisi kekinian.

2. Kesejahteraan rakyat adalah tolak ukur yang selalu menjadi spirit pemegang keputusan baik dalam lembaga eksekutif, legislatif dan yudikatif.

\section{Daftar Pustaka}

Al-Qurțūby. Tafsir al-Qurțiby al-Jämi' li Ahkām al-Qur'ān. Beirut: Dār Ar-Risālah, 2006.

Anonim. “Kasus Bulogate." Kompas, 19 Juni 2000.

Atok, A. Rosyid Al. "Ketetatapn MPR dalam Hirerarki Peraturan Perundang-undangan." Jurnal Pendidikan Pancasila dan Kewarganegaraan 25, no. 1 (Pebruari 2012).

Departemen Agama RI. Al-Qur'an Dan Terjemahannya. Semarang: Tanjung Mas Inti, 1992.

Fairuzabadi, Abū Ishāa al-Shirazy. Al-Luma’ fi Ușul al-Fiqh. Surabaya: Maktabah Muhammad Bin Ahmad Nabban wa Auladuh, t.t.

Fraksi Kebangkitan Bangsa DPR-RI. Buku Putih: Menegakkan Kebenaran. Jakarta: Bumi Selamat Printing, 2001.

Haramain, Malik. Gus Dur Militer dan Politik. Yogyakarta: LKiS, 2004.

Idri. "Sistem Politik dan Pemerintahan Islam dalam Perspektif Abū al-A'lā al-Maudūdy." Jurnal Al-Qānūn 11, no. 1 (t.t.): Juni 2008. 
Isa, Muhamad Yasin. Al-Fawa'id al-Jāniyyah. Beirut: Maktabah AlBuhūūh wa al-Dirāsāt, 1997.

Jindan, Khalid Ibrahim. Teori Pemerintahan Islam; Menurut Ibnu Taimiyah. Jakarta: Rineka Cipta, 1994.

Junaidy, Abdul Basith. "Menimbang Maṣlaḥah sebagai Dasar Penetapan Hukum (Kajian terhadap Pemikiran Muhammad Abu Zahrah)." Jurnal Al-Qänūn 18, no. 2 (Desember 2015).

Karmi, Hasan S. Al-Mughni al-Kabir Plus: A Dictionary of Contemporary English-Arabic. Beirut: Librairie du Libanon, 1944.

Muwahid. "Sistem Ketatanegaraan Indonesia Pasca Amandemen UUD 1945." Jurnal Al-Qānün 13, no. 2 (Desember 2010).

Muzammil, Iffah. "Mașlaḥah sebagai Sumber Hukum Islam menurut Najm al-Dīn Al-Ṭûfy." Jurnal Al-Qānūn 13, no. 1 (Juni 2010).

Naim, Abu. "Tipologi Kepemimpinan Politik Gus Dur." Darussalam: Jurnal Pendidikan, Komunikasi, dan Pemikiran Hukum Islam VI, no. 1 (September 2014).

Partanto, Pius A, dan Al-Barry. Pius A Partanto dan M. Dahlan alBarry. Kamus Ilmiah Populer. Surabaya: Arkola, 1994. Surabaya: Arkola, 1994.

Sjadzali, Munawir. Islam dan Tatanegara: Ajaran Sejarah dan Pemikiran. Jakarta: UI Press, 1993.

Sulistyoko, Arie. "Pemakzulan Presiden dalam Persepsi Konstitusi (Studi Kasus Presiden Abdurrahman Wahid)." Syariah: Jurnal Hukum dan Pemikiran 16, no. 1 (Juni 2016).

Widodo, Hananto. "Politik Hukum Hak Interpelasi Dewan Perwakilan Rakyat Republik Indonesia." Jurnal Rechtsvinding: Media Pembinaan Hukum Nasional 1, no. 3 (Desember 2012). 